\title{
Internationalization Project to Face the Uncertainties of Work Market
}

\author{
Claudio R. Brito \\ President of IEEE Education Society \\ President of COPEC - Science and Education Research \\ Organization \\ Santos, Brazil \\ drbrito@,copec.eu
}

\section{Henrique D. Santos}

Vice President for Conferences of IEEE Education Society

Director of Information Systems Department at University of Minho

Guimarães, Portugal

hsantos@dsi.uminho.pt

\section{Luis A. Amaral}

President of CCG - Computer Graphics Centre

Professor of Information Systems Department at University of Minho

Guimarães, Portugal

amaral@dsi.uminho.pt

\author{
Melany M. Ciampi \\ President of WCSEIT - World Organization on Systems \\ Engineering and Information Technology \\ Secretary of IEEE Education Society \\ Braga, Portugal \\ drciampi@,copec.eu \\ Rosa M. Vasconcelos \\ Board of Governors of IEEE Education Society \\ President of Pedagogic Council of Engineering College at \\ University of Minho \\ Guimarães, Portugal \\ rosa@det.uminho.pt \\ Victor A. Barros \\ Executive Secretary of COPEC - Science and Education \\ Research Organization \\ Researcher of Information Systems Department at \\ University of Minho \\ Jataí, Brazil \\ victor@,copec.eu
}

\begin{abstract}
This paper is a work in progress research to practice project developed in order to enhance the quality of engineering programs. It is a fact that the so called global work market has become challenging and increasingly multicultural The not so new trend for university programs is the internationalization that is a strategic element to raise the quality of courses and thus attracts more students. This trend has made many universities to revise and update their strategies so that their students and their graduates can have the essential academic and professional skills that allow them to enter and to stay in the work market. Although it is not the only measure that guarantees a good course it adds value for the formation of the new professional. The objective is to make it more attractive and promote the double diploma in order to higher the quality of the offered programs.
\end{abstract}

Keywords - international cooperation, double diploma, strategic plans, multicultural skills, development opportunities.

\section{INTRODUCTION}

Presently internationalization constitutes another way in which universities, in many countries can obtain the necessary support from education development agencies for the growth of teaching, research and extension. Universities find in international cooperation programs an increase of competence in the development of their historical, educational and social missions.

The internationalization of any College is important once it enriches the students' horizons and prepare them to become the next generation of leaders in their nations and who also can work in different cultures and countries to overcome challenges and so to cooperate in solving shared global problems.

Any type internationalization to be considered could not be different for universities and colleges, is a laborious process and demands a great deal of diplomacy and commitment to get to the final goal.

Another aspect is the strong partnership that must be built among all the people from all involved institutions.

Seen by the current perspective, the inter institutional international cooperation, in its essence, implies some fundamental conditions such as [1]:

- to recognize the existence of people, protagonists of cooperation;

- all participants in the process should be involved and committed to the forms of cooperation, in accordance with the availability of human and financial resources; 
- the goals of cooperation have to be clearly defined and consistent with implementation strategies;

- projects should be included in the strategic development plans of the institutions optimizing the benefits and improving the levels of development of the partners; - the activities must be specifically established, respecting previously defined schedules and budgets; and

- finally, it is important the establishment of mechanisms directed to the development and evaluation of cooperation actions.

Establishing internationalization strategies requires the observation of some characteristics that may limit the area of activity, such as: restrictions in terms of geographical location of partner universities; existence of language barriers; and areas of excellence in teaching or research, as well as the level of development of the country where the institution is located.

There is a general consensus that the internationalization of higher education strengthens its academic programs but also benefits the countries economy, enhances cultural understanding, and ultimately leads to a better future for the globalized world in which we live and will live [2].

Some authors argue that the popularity of the term 'internationalization' in the education field appeared since the early 1980 s and in $1990 \mathrm{~s}$, the debate on using the term 'international education' centered on differentiating it from comparative education, global education, and multicultural education. Wilson (2013, p.30) argues "internationalization is an increasingly important strategic priority not only for institutions but also for governments, which are increasingly aware of the importance of universities in supporting national and regional competitiveness" [3].

Still it is a strategy pursued by many high education institutions.

Anyway he objective of the proposed project is to make the programs more attractive and promote the double diploma in order to raise their quality. It has been developed for a private university that sees the internationalization as an opportunity not only to raise the quality of its programs but also to attract more brilliant students aiming the further expansion of scientific research that is now modest.

\section{SOME DiscusSIONS ABOUT THE RELATION OF CONTEMPORARY EDUCATION AND WORK MARKET}

The common problem presently is the division between university teaching and work in the modern digital, global world. Many newly trained engineers do not always have the skills they need to succeed upon completion of the course. Several studies show that, on average, $40 \%$ of young graduates worldwide do not have the skills to make appropriate decisions outside of the university environment in which they have spent 4 or 5 years.

The problem may arise from different environments: on one hand, the highly structured environment of educational programs; and, on the other hand, the changing dynamic and challenging modern working environment.
The academic environment by its structuring characteristics needs to have schedules and study guides, and followed by the students for the construction of the knowledge and that should be taken seriously. But in the workplace, as professionals, the success implies in their capability to be creative, innovative and adaptable. In other words, newly trained professionals are losing the skills needed to adapt to the workplace, where the tasks to be performed cannot simply be learned in a textbook for a semester. Thus, it can be said that the so-called "soft" skills, in turn, are obtained as a derivative of how students actually learn, but not exactly what they learn.

One way to improve this transition from the academic environment and the work environment is to modernize the students' curriculum. Nowadays there are harsh criticisms of the teaching methods that lead the professional to a long period of adaptation. However, there has to be a starting point that can start a new academic journey, that allows students to acquire the necessary skills needed for a short adaptation to the job market [4].

Anther aspect is related to the governments that need to invest in the entire educational system, which builds workforce skills, from the basic education until the university levels. It is up to public and private institutions initiatives to offer opportunities for young ambitious talented professionals, who can cooperate for a better future of generations to come. Still there is no better place than universities to offer these opportunities, pushed by the enterprises collaboration offering internships opportunities.

It is important for nations to train highly skilled native-born citizens as well as to attract highly skilled immigrants in order to be competitive in a global scale and assure a future for the humanity.

\section{THE PROPOSAL}

To understand the relevance between school disciplines and how a career-building journey takes place, it is helpful for young people to understand how work dynamics happens. The ability to make connections between different skill sets is the basis of the development of the future engineer's career plan. This is what young graduates will do for the rest of their lives as they progress in their own careers. Developing a successful career requires that they continually ask themselves, "Where can I go from here with my current skills? Given my vision and skill set today, what additional skills will increase my ability to achieve my vision?" The role of the engineering school also includes helping them to initiate this process of questioning, already during their formation hence the importance of a good engineering course.

Engineering courses actually are full of important core subjects that enables the students to develop their professional careers as engineers, however it is necessary to innovate and find ways to embed the curricula with important topics to fulfill the new requirements of what is called global world trends.

Engineering skills are internationally portable, leading to international mobility, which makes the profession extremely interesting. Intercultural skills, knowledge of languages and cultural prejudice management are very important also, 
because opportunities are extra boundaries and it is important to be able to adapt to any different cultural environment [5].

Another fact, which is not new, is that many engineering students have a lack of knowledge about what being an engineer really means. The first 3 years are particularly intense and hard. The authors of the project suggest that a possible way to improve their perception about the profession is to implement a new kind of course, more enticing and dynamic.

This is one of the proposals of COPEC's engineering education research team: to embed a course with a more interesting activity for students, earlier, in the first year. It is a short-term workshop in order to show students the possibilities of performing as engineers in a global environment - a project developed for a private university in order to reduce retention rate among students of engineering courses. It is part of the internationalization of the Engineering Program due to the need not only to raise the quality of the program as well as to start the internationalization process of the university that is the goal.

The main idea is during the first 3 months period, in the second semester of the $1 \mathrm{st}$. year, provide the students with different classes, which are more dynamic, due to the mix of site visits, lectures, project proposals, travel period and project presentation.

It intends to be for sure a very dynamic experience that provides students a clear view of what it is to be an engineer and what are their possibilities for the future.

The main objective of this project proposal is to provide a sophisticated period to implement integrated environments for teaching/learning systems. The idea is to provide a way to reduce the evasion of engineering courses, showing a glimpse of what it is to be an engineer and to see that there are wide varieties of opportunities worldwide [6].

\section{COPEC - SCIENCE AND EDUCATION RESEARCH ORGANIZATION}

This is an organization of about 18 years of existence a multi-disciplinary organization that is a leader on advance science and its application to the development of technology serving society. It started its activities sixteen years ago and since then this organization has made a major contribution to the development of science and education, working to increase the best practices in several research fields.

Integration activities promoted by COPEC provide a qualified coordination and building partnerships, because COPEC is an organization that brings together scientists who share the mission of promoting and developing science, technology and education.

The objectives of COPEC are to promote professionalism, integrity, competency, and education; foster research, improve practice and encourage collaboration in different fields of sciences.

Contents, tools and services provided by COPEC, through courses, publications and consultations, with national and international experts, contribute to the promotion of the professional who wants to be privy of new achievements and service of men to technology.

COPEC enjoys respect and recognition internationally characterized by the open discussion, the free exchange of ideas, respectful debate, and a commitment to rigorous inquiry. Its IIE - International Institute of Education - is a bold and resilient source of innovation in higher education [7].

\section{The Project Design}

The starting point of this project development is the establishment of some actions in phases, in steps that leads to the first goal of internationalization of the Engineering College Programs in first place, followed by other programs that the University offers.

It is important to point out that it is not a generic proposal. It has been designed for a university. It is not a philosophical discussion about internationalization and its benefits.

The results will come step by step with solid establishment of activities specially designed with the purpose of enhance the quality of the programs offered by the university.

The phases are:

Table 1. Project Phases.

\begin{tabular}{|l|l|}
\hline \multicolumn{1}{|c|}{ Phases } & \multicolumn{1}{c|}{ Description } \\
\hline 1- Conception & $\begin{array}{l}\text { At this stage, it is established the estimates of } \\
\text { achievement, dates, allocated resources, } \\
\text { establishment of guidelines and elaboration of } \\
\text { project outlines are discussed. The product of this } \\
\text { stage is the project design }\end{array}$ \\
\hline 2-Structuring & $\begin{array}{l}\text { This stage involves all the technical part and } \\
\text { activities necessary for the accomplishment of the } \\
\text { project as: Hiring the operational team people; } \\
\text { Basic schedule; Services to be contracted; } \\
\text { Establishment of organization chart; among others. } \\
\text { The product of this step is the entire action plan } \\
\text { and timeline of final activities }\end{array}$ \\
\hline 3- Execution & $\begin{array}{l}\text { This stage consists of executing the project } \\
\text { according to the action plan and timeline } \\
\text { established between the stakeholders. The product } \\
\text { of this step is the execution of all activities } \\
\text { programmed in the project action plan. }\end{array}$ \\
\hline 4- Closure & $\begin{array}{l}\text { This stage consists of the closing of the project and } \\
\text { the preparation of the reports with information } \\
\text { about the project, with the necessary documents } \\
\text { and documents to render accounts with the } \\
\text { institutions involved in the project. The product of } \\
\text { this step is the final report with the detailed } \\
\text { description of all the actions of the project. }\end{array}$ \\
\hline
\end{tabular}

The Developed Activities are:

Table 2. Activities.

\begin{tabular}{|l|l|}
\hline \multicolumn{1}{|c|}{ Terms } & \multicolumn{1}{|c|}{ Activities } \\
\hline Short & $\begin{array}{l}\text { Establishment of an International Relations } \\
\text { Office in Europe; } \\
\text { Identification of partners to establish } \\
\text { agreements in Europe and USA; } \\
\text { Scheduling visits to partner universities. }\end{array}$ \\
\hline Mid & $\begin{array}{l}\text { Short-term courses outside the country for } \\
\text { undergraduate, graduate and high school } \\
\text { students; } \\
\text { Agreements with universities in Europe, USA, }\end{array}$ \\
\hline
\end{tabular}




\begin{tabular}{|l|l|}
\hline & $\begin{array}{l}\text { and Canada; } \\
\text { Implementation of top pioneer courses with } \\
\text { unique characteristics }{ }^{* 1} \text {. }\end{array}$ \\
\hline Long & $\begin{array}{l}\text { Courses offered with double diploma; } \\
\text { International Courses; } \\
\text { Exchange of students and teachers; } \\
\text { Receiving students from outside }{ }^{* 2} ; \\
\text { Opening of the advanced campus in Europe. }\end{array}$ \\
\hline
\end{tabular}

*1 - The creation and offer of Cyber Security Courses on 3 different levels:

- High school;

- University graduate;

- Postgraduate.

Short international courses for:

- Specialization;

- University Graduation;

- Executive MBA;

- Specialization Course for Engineering Teachers International Engineering Educator.

*2 - Focus on receiving students from CPLP (Community of Portuguese Language Countries) component countries.

About the agreements with other universities, they are an umbrella type with several possibilities such as student and teacher exchange, project development, double enrollment and others stipulated by the colleges involved [8].

It is important to start in Europe for several reasons, as follows:

- the main one being the visa exemption for Brazilians;

- the second one Europe has a very high level of cultural life; and

- depending on time of the year, depending on the season, the flying tickets have a more reasonable price.

It is important to go to Canadian universities and US as well. It is under the perspective of the possibility of offering:

- Short courses;

- Workshops; and

- Joint projects and courses.

The last accomplishment will be the establishment of an advanced Campus of the University in Europe once it is a very important economic block besides the fact that there is the Portuguese Speaking Country - Portugal one of the most important colonizer countries in the world history.

In fact the project description uses the future tense because it is the description presented to the board of trustees of the university. So it had to be written in the future tense.

\section{THE IMPLICATIONS OF INTERNATIONALIZATION FOR THE UNIVERSITIES}

Because there are many good reasons to internationalize, there is no right or wrong approach to entering the international educational market. Different circumstances will be prevalent in different countries and for different cultures. In all cases,
COPEC's engineering education research team strongly recommends serious reflection and much preparation.

It requires a research on foreign property acquisition as well as understanding the real estate culture of the chosen country. By taking the courses abroad, universities are replicating their educational models to another set of circumstances, a different place and culture, with a different job market, demands, needs, and expectations.

The question is: is it worth it?

And the answer is: absolutely.

If institutions strive for success there is a fundamental action that is to seek the help of natives and professionals. Becoming international or even global can be one of the most intelligent and profitable moves to improve the quality of the organization, attract new talent and increase its resources whether human or financial. Otherwise, institutions would be neglecting increasing quality of education, acquiring new knowledge and experience and, more importantly, more opportunities for research development [9].

Of course the best program to start internationalization process is the Engineering. It is due to the portability of engineering diplomas and the wide possibilities for engineers to work in any place in the world. Along history engineers have been developing projects in different countries in the world. The Panama Canal for example, has been designed and developed by engineers first from a French construction team in the 1880s. The United States commenced building a canal across a 50-mile stretch of the Panama isthmus in 1904. The project was helped by the elimination of disease-carrying mosquitoes, while chief engineer John Stevens devised innovative techniques and spurred the crucial redesign from a sea level to a lock canal [10].

Once getting success with engineering programs the idea is to work more with other programs and get to the point that in every program there is a possibility to have students and teachers going abroad and also receive students and teachers from abroad.

\section{Plans FOR EVALUATION OF IMPLEMENTATION}

The organization responsible for the design and implementation of the internationalization process of the particular university has established a process of steps evaluation. For example, for the international office in Europe ties there is a survey to be applied to the international relations officers in the university. The goal is to evaluate the effectiveness of the actions taken abroad in order to identify partner universities and the schedule for visits to sign agreements of mutual activities.

After having students (graduation/under-graduation level) travel abroad, a survey will be conducted among them to evaluate the quality of the courses and what can be improved.

For every activity organized there is an evaluation form for the involved staff and people benefitted by the project to make it better and get to the final goal - to establish a campus abroad. 


\section{FINAL CONSIDERATIONS}

In terms of professional career for many employers, no skill is more valuable than a foreign language. Many consider English as the "lingua franca". English as a medium of instruction is a prevalent way to offer international higher education as it continues to attract international students. English-taught degree programs continue to develop in many countries worldwide. With the multilingual environment come new challenges and responsibilities. Although the continued prominence of English is uncertain English continues to play an important role in international higher education as well as in work places [11]

Nowadays one person is considered literate when $\mathrm{s} / \mathrm{he}$ speaks the mother tongue, English and another foreign language. So the first positive aspect of an experience abroad is the learning of another language besides English.

Teachers living abroad learn foreign languages or get particularly interested in foreign cultures, and it is likely that sooner or later they will be interested in seeing if the internationalization opportunities of their career would be appropriate for their lives. International trips not only for teachers, but also for the students promotes the enrichment of the academic experience. And this attracts more young people to pursuing a career that involves college or university education.

When students search a university program for study they are considering more aspects than just the brand, ranking level and reputation of an institution. They consider the quality and value, including costs, career prospects, and student experiences of the institution, all aspects that have increasingly become important in the student choice process. The different opportunities that the university can provide is also important and study abroad is one of them.

In general students, not only from abroad, they all seek out valuable quality experiences, anything from feeling welcome on campus, to accessible and valuable career services and to student accommodations. Higher education institutions shall continue to focus on creating and nurturing quality student experiences with the aim of retaining students national or international.

The future of higher education as expected will continue to be shaped and changed by global phenomenon. With evolution, come opportunities and challenges so keeping track of global higher education trends allows education institutions to be one step ahead and plan accordingly for the future.

The proposed internationalization project comes as an answer for the university that currently feels the need fostered by the incentives of governmental agencies as well as a way to attract more bright students and be at the top ranking. So far the organized actions that have been put in place are the agreements with universities abroad - carried out by the international office and a workshop in Europe for a group of students of the Civil Engineering Program. The project is being accomplished and for future work it is expected some results offered by the evaluation of the activities.

\section{ACKNOWLEDGMENT}

This work is financed by FEDER funds through the Competitivity Factors Operational Programme - COMPETE: POCI-01-0145-FEDER-007043 and by national funds through FCT - Foundation for Science and Technology within the scope of the project POCI-01-0145-FEDER-007136 and project UID/CEC/00319/2013.

\section{REFERENCES}

[1] https://www.britishcouncil.org.br/atividades/educacao/internacionalizaca o/capacitacao-ensino-superior

[2] http://www.capes.gov.br/bolsas-e-auxilios-internacionais?view=default

[3] https://www.researchgate.net/publication/313826172_Internationalizatio n_as_Investment_for_Higher_Education_Institutions_Introducing_a_Fra mework to Enhance Investment in Internalization Practices

[4] Moskal, Marta "International Students Pathways Between Open and Closed Borders: Towards a Multi-scalar Approach to Educational Mobility and Labour Market Outcomes." International Migration 55.3 (2017): 126-138.

[5] Daneva, Maya; Chong Wang; Hoener, Patrick "What the job marke wants from requirements engineers?: an empirical analysis of online job ads from the netherlands." Proceedings of the 11th ACM/IEEE International Symposium on Empirical Software Engineering and Measurement. IEEE Press, 2017.

[6] Ciampi, Melany M.; Vasconcelos, Rosa. M.; Amaral, Luis A.; Santos, Henrique D.; Barros, Victor A. "Engineering Course Specially Designed to Face Retention Issue" Proceedings of the 45th SEFI Annual Conference, 2017.

[7] http://copec.eu/menu/mission/

[8] https://www.merriam-webster.com/dictionary/agreement

[9] Hudson, Paul F.; Hinman, Sarah E. "The integration of geography in a curriculum focused to internationalization: an interdisciplinary liberal arts perspective from the Netherlands." Journal of Geography in Higher Education 41.4 (2017): 549-561.

[10] https://www.history.com/topics/panama-canal

[11] http://www.scielo.br/pdf/aval/v22n3/1982-5765-aval-22-03-00614.pdf. 